\title{
Factors Affecting Counterfeit Products Purchase Decision
}

\author{
Saed Adnan Mustafa ${ }^{1}$ and Randolf von Narbay Salindo ${ }^{1}$ \\ ${ }^{1}$ Business Administration Department, Sur University College, Sur, Oman \\ *Correspondence: Saed Adnan Mustafa, Email: said_es@yahoo.com
}

\begin{abstract}
The purpose of the research was to identify the factors impelling the buyers' attitude towards the purchasing intention of counterfeit products among customers. The conceptual framework is proposed by different studies. All measures used were evaluated in terms of their internal consistency also in terms of discriminant validity and convergent validity to validate the data and the questionnaire. A survey was carried out on the Oman market with 350 respondents. The results of this research found that integrity and social status have a positive relationship and significantly affected the attitude of consumers when they made their purchasing decisions while price consciousness and novelty have a negative relationship with customer attitude.
\end{abstract}

Keywords: PLS, Counterfeit, Integrity, Novelty, Consumer, Attitude, Price consciousness

\section{ARTICLE INFORMATION \\ Author(s): Saed Adnan Mustafa and Randolf von Narbay Salindo Received: 18 Oct, 2020; Accepted: 04 Jan, 2021; Published: 25 Feb, 2021 e-ISSN: 2347-4696; \\ Paper Id: BMN-IJBMR-2020-16; \\ Citation: doi.org/10.37391/IJBMR.090108 \\ Webpage-link: \\ https://ijbmr.forexjournal.co.in/archive/volume-9/ijbmr-090108.html}

\section{INTRODUCTION}

Cordell, et al., describe counterfeiting as "any unauthorized produced services or goods whose special characteristics are protected as intellectual property rights (patents, trademarks, and copyrights) constitute product counterfeiting. Nearly anything, from clothing to electrics, pharmaceuticals, bleach and dyes, food, books, and more, can be counterfeited these days. This means that counterfeiting is becoming a common thing on the market. Around $35 \%$ of customers have been shown to continue to buy falsified products [1, 2]. Since competition is the industry's main driving force, several researchers have argued that the demand for counterfeits by consumers represents one of the key reasons for this trend to rise [3].

In addition, counterfeiting does not look like other ways of infringement of intellectual property such as grey market products. Noor, et al. [4] has used several scales evaluating the characteristics and meaning of gray market goods for counterfeits, which are undeniably distinct. Grey market goods apply to the outsourced overruns of companies sold via unlicensed networks $[5,6]$, whereas counterfeiting involves a copy of the original article illegally made. According to Varghese, Al-Badi, \& Al-Qartoobi [7], pointed out that many reports and studies are dealing with counterfeit products in Oman and also the fact that the Oman administration is extremely cautious and determined to eliminate this danger. We feel that the 18-25 years youth of Oman, who make up the majority of the population, tend more toward fashion, brands, and glamour. In our sample, the majority of respondents were young; $43 \%$ being between the ages of $18-28$. One of the finding is that young consumers are more interested in purchasing counterfeit products that copy famous brands to' rob' their popularity. Furthermore, for customers to purchase counterfeit products in Oman the demographical disparities will also play a major role. It can be inferred from these claims that a significant number of studies emphasize the factors that affect the attitude of the customer to purchase such faked products. This study aims to find the main factors that may affect the customer parching decision and what motivate them to buy the counterfeit product in Oman market.

\section{LITERATURE REVIEW}

\subsection{Attitude}

"Attitude is a known predisposition for positive or unfavorable action concerning a particular object." [8]. Many claim it corresponds strongly with one's motives, which in effect are a rational conduct predictor [9]. If a consumer's stance on fake products is positive, then a consumer has a strong chance to think of a fake product, but if the mind-set of a customer is not positive, the person will probably not think twice about a fake product.

\subsection{Price Consciousness}

Price is an important element in influencing the behaviour of customers and has been extensively studied. The theory of ranges implies that the scale of reported customer meetings is used to set lower or higher expectations for consumers so that their position depends on the attractiveness of market prices in this area. The reference price has been debated as a factor that has a major effect on customer purchasing behavior. Following the combination of the theory of adaptation and pricing, the internal price of reference was defined as an adaptation based on recent pricing experience [10]. In this sense, Fink, et al., [11] found that the lowest price plays an important role as an indicator for a reference price, whereas past brand prices seem to become the most significant predictor over time. 


\subsection{Integrity}

Fixing fundamental principles such as honesty excludes the decision on succumbing to unethical activities [1]. Personal ethical principles and compliance with the law determine integrity. When consumers consider honesty as important, they will be less likely to see counterfeit goods as advantageous, but if consumers do not give priority to honesty at all, they will succumb to buying counterfeits [12].

\subsection{Social Status}

It has been defined by Ang [13] that social status is a social hierarchy or the position one owns concerning responsibility, prestige, or honor related to social influence and the effect that others have on consumer's behavior. Purwanto, et al., [14] dwelt into the theory of status and believed that, consuming extravagant products, it depicts an individual's supremacy of status to themselves and others. In addition, Qin, et al., [15] also elaborated on social status as the honor an individual holds with any particular position within society at large.

\subsection{Novelty Seeking}

The quest for novelty is driven by people's curiosity for variety and distinction $[16,17]$. A customer who is inclined to try new products is likely to cultivate a favorable attitude to those fake goods. Consumers looking for innovation are especially biased towards low-risk goods. The low cost of counterfeit goods makes it very easy to meet the market for innovation and curiosity $[16,17]$.

\section{METHODOLOGY}

The customers who live in Oman were surveyed using a questionnaire. As the goal of the study is to analyze the factors which affect the choice of a counterfeit product for purchase in Oman, our target population included all customers without regard to companies in particular. A total of 300 customers have been identified, 320 of whom have been surveyed. The surveys have been distributed in different states, including Muscat, Sur, Suhar, and Ibraa, to the customers in Oman. Roscoe [18] has indicated that most studies are suitable for sample measurements greater than 30 and less than 500. The data obtained were analyzed in version 17.0 and Partial Least Square (PLS) with PLSS software.

\subsection{Measurement of Variables}

A questionnaire assessing the factors influencing the decision to buy counterfeit goods has been created. The first steps in the questionnaire were taken employing previous literature indicators [19-22]. Before confirmation of the questionnaire, it was used in the pre-test to recognize any vulnerabilities and issues. To allow for the pretesting, 50 customers from Sur city were contacted by telephone and 30 of them had given their agreement to participate in the pilot study. A 5-point Likert scale "strongly disagree $=1$, to "strongly agree $=5$ " was applied. Also in terms of convergent and unequal validity, all interventions used have been tested for their internal consistency. External tests of accuracy suggest that taking into account the Cronbach results obtained [23], the quality of each calculation is high.

\section{RESULTS AND DISCUSSION}

\subsection{Confirmatory Factor Analysis}

Confirmatory factor analysis is used to determine that the data used in each of the five independent variables and models of the dependent variables is a strong fit. The confirmatory factor analysis output (five items) therefore indicates that two items (P4 and P5) have been excluded after confirmatory factor analysis or price analysis, and the other three items (P1, P2, and P3) were used. The key analysis reveals that all of the products have a factor loading of more than 0.70. This indicates that the items have a strong connection to the factor with factor loadings of over 0.70 [24].

Furthermore, integrity has four Items; the result of CFA reveals that all of the items have a factor loading of more than 0.70 . Social status has five Items; the result of CFA reveals that all of the items have a factor loading of more than 0.70 . Novelty seeking has four Items; the result of CFA reveals that one item (NO4) was deleted while the other three remaining items (No1, No2 and No3) were analyzed and showed that all the items have a factor loading of more than 0.70. Finally, the attitude has four items: the result of the CFA reveals that all the items have a factor loading of more than 0.70 .

\subsection{Convergent Validity and Reliability}

Based on the results of the ANCOVA, we determined that the type of training makes the converging validity of the measurement explained how many elements continuously converge to quantify a particular term. It can be measured through composite reliability (CR), average variance extracted (AVE), and factor loadings criteria [24]. We analyzed the factor loadings and cross-loadings of the items to identify issues relevant to the research items to fulfill the requirement of a research system validation. To assess the goodness of loadings of products, Hair et al., 2010 proposed a 0.7 limit. As shown in Table 2, the loading of all items is above the recommended value of 0.7 [24]. In other words, figure 1 findings demonstrate that all the items are heavily loaded by their respective factors as opposed to other factors.

\begin{tabular}{|c|c|c|c|c|}
\hline Construct & items & C. Alpha & C.R & AVE \\
\hline Price & 3 & .73 & .84 & .65 \\
\hline Integrity & 4 & .85 & .90 & .70 \\
\hline Social status & 5 & .83 & .88 & .60 \\
\hline Novelty seeking & 3 & .88 & .92 & .81 \\
\hline Attitude & 4 & .85 & .90 & .69 \\
\hline
\end{tabular}

Table 1: Measurement model result.

The next step, of convergent validity to validate the result was examined the composite reliability. The reliability of the composite shows whether a set of items reliably show the latent structure [24].

As shown in Table 1, the composite reliability ranged from 0.84 to 0.92 which is greater than the recommended value of 0.7 . This indicates the result is valid and can proceed to the next step [24, 25]. Furthermore, the average variance extracted (AVE), which refers to the average variance extracted between 
the items are tested. AVE values should be higher than 0.5 , as indicated by Barclay, et al. [26]. It implies that in calculating the concern variable, the set of objects has a corresponding convergence. The AVE values of all the variables were between 0.60 and 0.81 as shown in the results of Table 1 . Thus the measures used showed that the result is valid to be tested and validated.

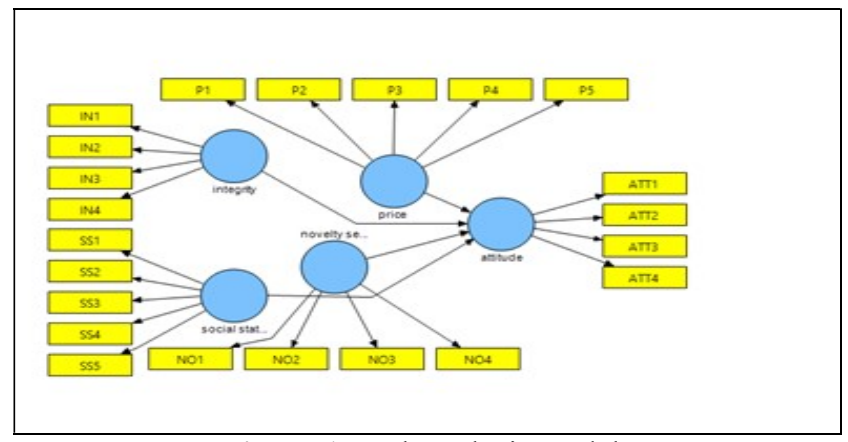

Figure 1: Path analysis model.

\subsection{Discriminant Validity}

The next theoretical process involved assessing the discriminant validity of the measuring model. This ensures that the measurement variables do not overlap with other variables [27]. As illustrated by Table 2, the AVE for each variable is higher than the cross-correlation between those variables and other variables. From the variables validity analysis and convergent validity, the validity of the variables of the measure can be concluded.

\begin{tabular}{|l|l|l|l|l|l|}
\hline & Attitude & Integrity & Novelty & Price & $\begin{array}{l}\text { Social } \\
\text { status }\end{array}$ \\
\hline Attitude & .69 & & & & \\
\hline Integrity & .597 & .70 & & & \\
\hline Novelty & .614 & .600 & .81 & & \\
\hline Price & .220 & .175 & .196 & .65 & \\
\hline $\begin{array}{l}\text { Social } \\
\text { status }\end{array}$ & .554 & .526 & .55 & .225 & .60 \\
\hline
\end{tabular}

Table 2: The discriminant validity.

\subsection{Testing the Research Model}

\begin{tabular}{|l|l|l|l|l|l|}
\hline $\begin{array}{l}\text { Hyp } \\
\text { o }\end{array}$ & IV & DV & $\begin{array}{l}\text { Path } \\
\text { Coefficie } \\
\text { nt }\end{array}$ & $\begin{array}{l}\text { T- } \\
\text { valu } \\
\text { e }\end{array}$ & Result \\
\hline H1 & $\begin{array}{l}\text { Price } \\
\text { concciousn } \\
\text { ess }\end{array}$ & $\begin{array}{l}\text { Attitu } \\
\text { de }\end{array}$ & 0.038 & 1.84 & $\begin{array}{l}\text { UnSupport } \\
\text { ed }\end{array}$ \\
\hline H2 & Integrity & $\begin{array}{l}\text { Attitu } \\
\text { de }\end{array}$ & 0.328 & 3.83 & Supported \\
\hline H3 & Novelty & $\begin{array}{l}\text { Attitu } \\
\text { de }\end{array}$ & 0.551 & 0.95 & $\begin{array}{l}\text { UnSupport } \\
\text { ed }\end{array}$ \\
\hline H4 & $\begin{array}{l}\text { Social } \\
\text { status }\end{array}$ & $\begin{array}{l}\text { Attitu } \\
\text { de }\end{array}$ & 0.072 & 9.27 & Supported \\
\hline
\end{tabular}

Table 3: Hypothesis result.
The final results of this research indicated that integrity and social status showed a positive significant effect on attitude with indicators: integrity and attitude $(B=0.328, t$-value $=3.83$, $\mathrm{p}<0.001)$, social status and attitude $(\mathrm{B}=0.072$, $\mathrm{t}$-value=9.27). These results indicated that $\mathrm{H} 2$ and $\mathrm{H} 4$ were supported by the results of the study. While, price and novelty found to have a negative significant effect on attitude with indicators, price and attitude $(\mathrm{B}=0.038$, $\mathrm{t}$-value $=1.84)$, novelty $(\mathrm{B}=0.551$, $\mathrm{t}-$ value $=0.954)($ Table 3 , Figure 3$)$.

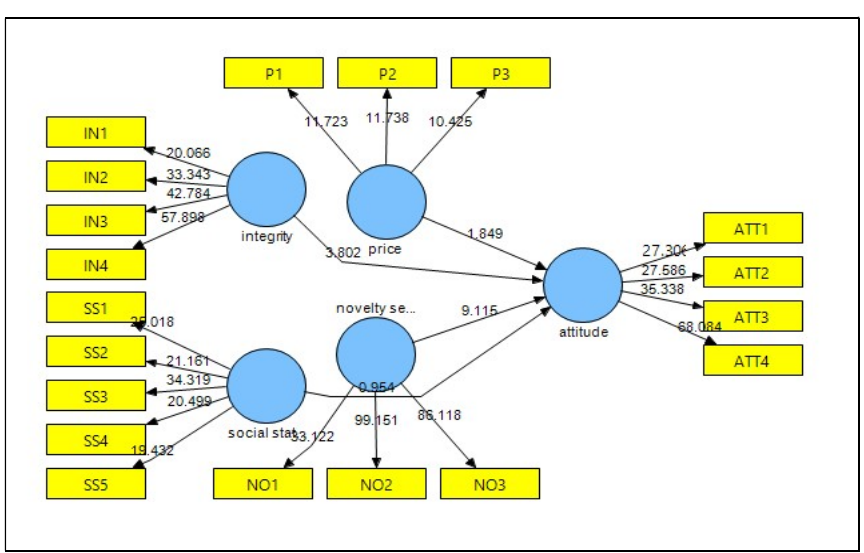

Figure 2: Bootstrapping result.

\section{CONCLUSION}

As a conclusion of the research finding, we can conclude that integrity and novelty in explaining the important factors that affect the customers' attitude among the customers in the Oman market. This research has proved that the important factors influencing the intention of customers to buy a falsified product are very much dependent on their attitude towards fake goods. These attitudes were strongly influenced by integrity and social influence. This research differs from various studies in recent years [1-3], but it is appropriate because of the scope of the analysis and its context.

This study is devoid of the product specification, further research could highlight the specific brand or product category in a different time frame. Demographic factors might also need to be weighed upon for future studies. Culture, age, occupation, income or nationality may determine the attitude of the consumers. Also, more different geographic areas would make a good area to be considered.

\section{REFERENCES}

[1] Jiang, Y., Miao, M., Jalees, T., \& Zaman, S. I. (2019). Analysis of the moral mechanism to purchase counterfeit luxury goods: evidence from China. Asia Pacific Journal of Marketing and Logistics.

[2] Eisend, M. (2019). Morality effects and consumer responses to counterfeit and pirated products: A meta-analysis. Journal of Business Ethics, 154(2), 301-323.

[3] Bian, X., Haque, S., \& Smith, A. (2015). Social power, product conspicuousness, and the demand for luxury brand counterfeit products. British Journal of Social Psychology, 54(1), 37-54. 


\section{Business and Management Research (IJBMR)}

Research Article | Volume 9, Issue 1 | Pages 51-54 | e-ISSN: 2347-4696

[4] Noor, M., Azila, N., Muhammad, A., Ghani, A., \& Ku Ishak, A. (2017). Does behavioral intention influence purchase behaviour of counterfeit products: a look at Malaysian consumers. Journal of Humanities, Language, Culture and Business, 1(1), 1-12.

[5] Fernandes, C. (2013). Analysis of counterfeit fashion purchase behaviour in UAE. Journal of Fashion Marketing and Management: An International Journal.

[6] Chaudhry, P. E., Zimmerman, A., Peters, J. R., \& Cordell, V. V. (2009). Preserving intellectual property rights: Managerial insight into the escalating counterfeit market quandary. Business Horizons, 52(1), 57-66.

[7] Varghese, T., Al-Badi, L., \& Al-Qartoobi, K. (2013). Counterfeit good business in Oman. Does any factors affect this business?. International Postgraduate Business Journal, 5(2), 1945.

[8] Ting, M. S., Goh, Y. N., \& Isa, S. M. (2016). Determining consumer purchase intentions toward counterfeit luxury goods in Malaysia. Asia Pacific Management Review, 21(4), 219-23.

[9] Herstein, R., Drori, N., Berger, R., \& Barnes, B. R. (2015). Anticounterfeiting strategies and their influence on attitudes of different counterfeit consumer types. Psychology \& Marketing, 32(8), 842-859.

[10] Bate, R., Jin, G. Z., \& Mathur, A. (2011). Does price reveal poor-quality drugs? Evidence from 17 countries. Journal of Health Economics, 30(6), 1150-1163.

[11] Fink, J., Schoenfeld, B. J., Hackney, A. C., Matsumoto, M., Maekawa, T., Nakazato, K., \& Horie, S. (2019). Anabolicandrogenic steroids: procurement and administration practices of doping athletes. The Physician and sportsmedicine, 47(1), 10-14.

[12] Montecchi, M., Plangger, K., \& Etter, M. (2019). It's real, trust me! Establishing supply chain provenance using blockchain. Business Horizons, 62(3), 283-293.

[13] Ang, I. (2001). On not speaking Chinese: Living between Asia and the West. Psychology Press.

[14] Purwanto, P., Margiati, L., Kuswandi, K., \& Prasetyo, B. (2019). Consumer motives for purchasing counterfeit luxury products: behind the status signaling behavior using brand prominence. Business: Theory and Practice, 20, 208-215.

[15] Qin, Y., Shi, L. H., Song, L., Stöttinger, B., \& Tan, K. F. (2018). Integrating consumers' motives with suppliers' solutions to combat Shanzhai: A phenomenon beyond counterfeit. Business Horizons, 61(2), 229-237.
[16] Rishi, B., \& Mehra, A. K. (2017). Key determinants for purchasing pirated software among students. International Journal of Technology Marketing, 12(1), 4-22.

[17] Hundal, B. S. (2018). Attitude of Indian consumers: A study of counterfeit luxury brands. ZENITH International Journal of Multidisciplinary Research, 8(9), 139-152.

[18] Roscoe, J. T. (1975). Fundamental research statistics for the behavioral sciences [by] John T. Roscoe.

[19] Phau, I., \& Teah, M. (2009). Devil wears (counterfeit) Prada: a study of antecedents and outcomes of attitudes towards counterfeits of luxury brands. Journal of consumer marketing.

[20] Rokeach, M. (1973). The nature of human values. Free press.

[21] Huang, J. H., Lee, B. C., \& Ho, S. H. (2004). Consumer attitude toward gray market goods. International Marketing Review, 21(6), 598-614.

[22] Lichtenstein, D. R., Ridgway, N. M., \& Netemeyer, R. G. (1993). Price perceptions and consumer shopping behavior: a field study. Journal of marketing research, 30(2), 234-245.

[23] Nunnally, J. C. (1994). Psychometric theory 3E. Tata McGrawHill Education.

[24] Hair, J. F., Ringle, C. M., \& Sarstedt, M. (2013). Partial least squares structural equation modeling: Rigorous applications, better results and higher acceptance. Long range planning, 46(12), 1-12.

[25] Fornell, C., \& Larcker, D. F. (1981). Structural equation models with unobservable variables and measurement error: Algebra and statistics.

[26] Barclay, D., Higgins, C., \& Thompson, R. (1995). The partial least squares (PLS) approach to casual modeling: personal computer adoption ans use as an Illustration.

[27] Compeau, D., Higgins, C. A., \& Huff, S. (1999). Social cognitive theory and individual reactions to computing technology: A longitudinal study. MIS quarterly, 145-15.

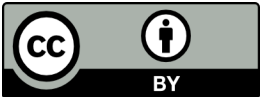

(C) 2020 by the Saed Adnan Mustafa and Randolf von Narbay Salindo. Submitted for possible open access publication under the terms and conditions of the Creative Commons Attribution (CC BY) license (http://creativecommons.org/licenses/by/4.0/). 